\title{
Not only the studies - a photoreport from the activity of the "Geotourism" Special Interest Group of the Student's Scientific Association at the AGH-UST
}

Nie samą nauką żyje student, czyli fotorelacja z działalności KN „Geoturystyka”

\author{
Mateusz Birówka \\ Student's Scientific Association, "Geotourism” Special Interest Group \\ at the Faculty of Geology, Geophysics and Environment Protection, \\ AGH University of Science and Technology, al. Mickiewicza 30, 30-059 Kraków, \\ e-mail:m.birowka@gmail.com
}

The "Geotourism" Special Interest Group of the Student's Scientific Association at the at the Faculty of Geology, Geophysics and Environment Protection, AGH-University of Science and Technology has been active since almost 10 years. During this time the association has attracted tens of enthusiasts interested in geotourism. Recently, over twenty ambitious, hungry for knowledge colleagues are active in our group, most of them studying the Tourism \& Recreation and/ or Geology \& Mining Engineering courses.

In 2012 our group has undertaken many activities focused on gaining the skills and experience in tourism industry. The first was organization of an information and promotion post during the Open Day of the AGH-UST (Fig. 1). The next was the preparation of the first cyclic event: the Argentinian Evening entitled "Argentina - the geoheritage in national parks". We gathered and heard the tells told by Dr. Marek Doktor about Argentina and its tourist and geotourist attractions. Then, we tasted the self-made argentinian couisine, which helped us very much to recognize what Argentina really is (Fig. 2).

An important activity of our group is the work on geotourist projects. In 2012 we run the II stage of project granted by the Rector of the AGH-UST. The project aims to develop the information boards for the Ojców National Park. We intend to design the new boards explaining to the visitors some geological processes, which can be observed at specific sites in the park selected by park authorities.

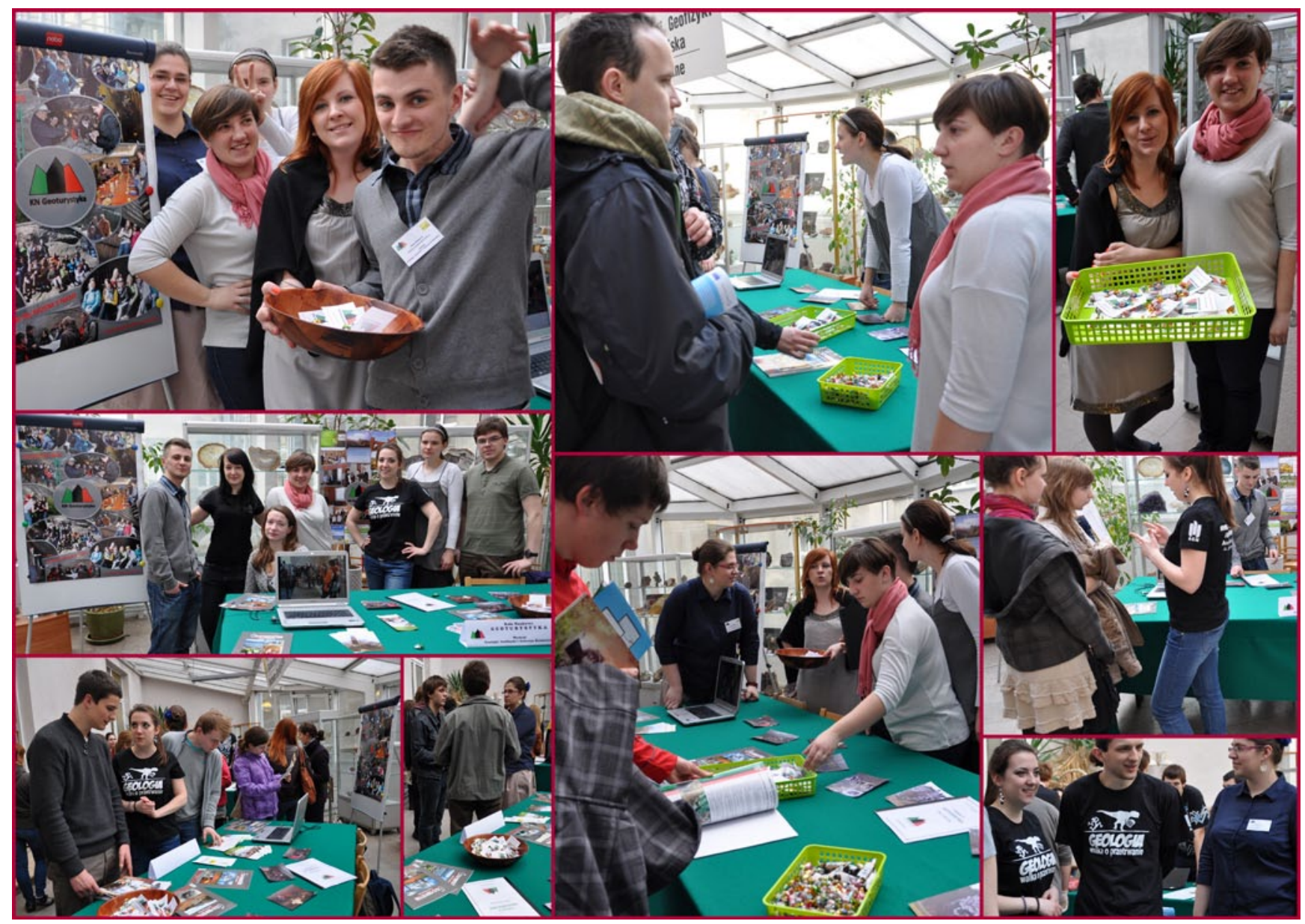

Fig. 1. A busy day at the Open Days of the AGH-UST. See you in Spring, 2013, phot. E.M. Welc • Pracowity dzień na Dniach Otwartych AGH. Zapraszamy ponownie wiosną 2013 roku, fot. E.M. Welc 

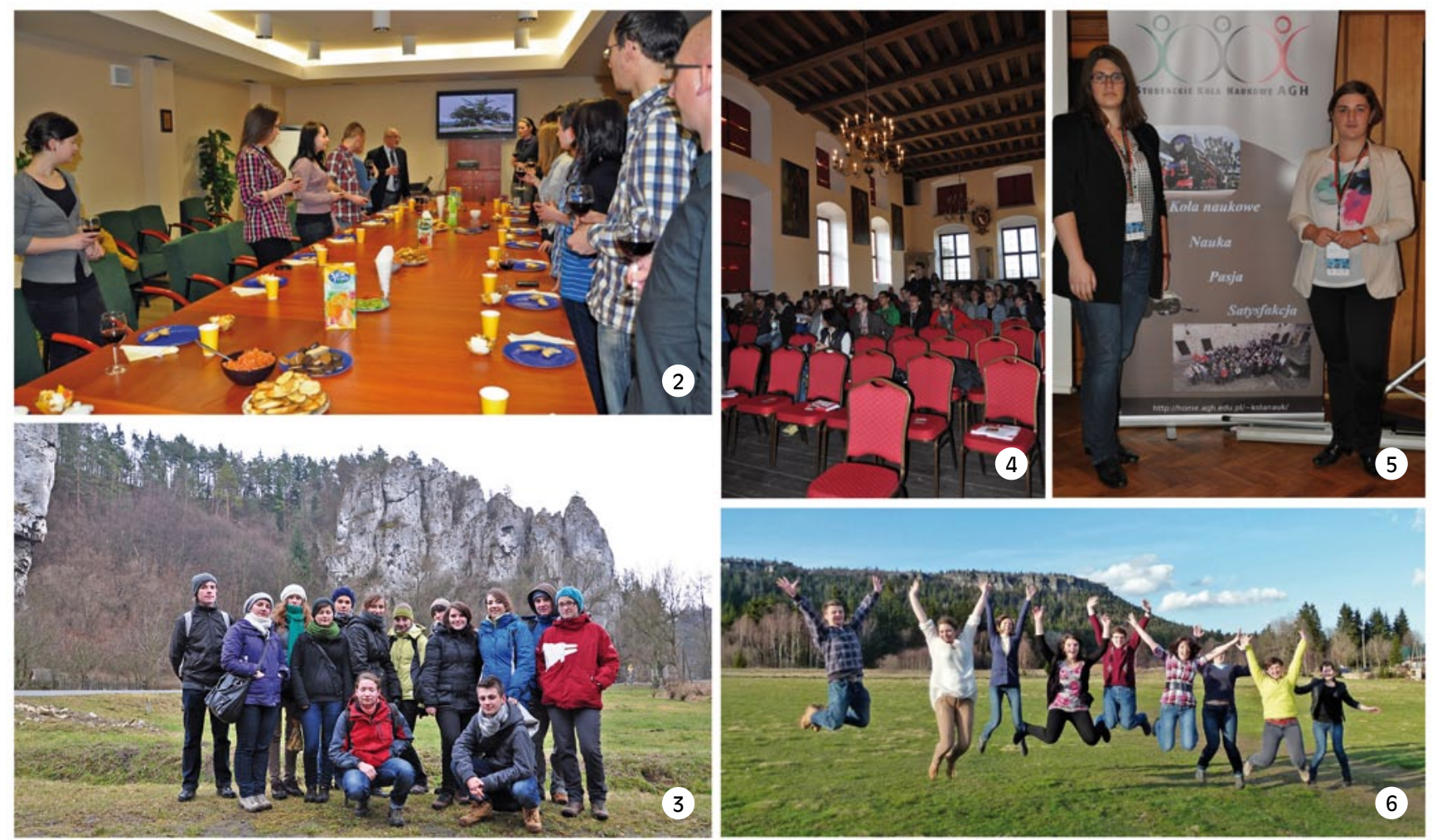

Fig. 2. The Argentinian Evening, phot. E.M. Welc • Wieczór argentyński, fot. E.M. Welc

Fig. 3. Field trip to the Ojców National Park, phot. E.M. Welc • Wyjazd terenowy do Ojcowskiego Parku Narodowego, fot. E.M. Welc Fig. 4. One of the Wiśnicz Castle rooms hosts the participants of the XVIIth Seminar of the Student's Scientific Association, phot. E.M. Welc • Jedna z komnat zamku w Wiśniczu gościła uczestników XVII Seminarium Kół Naukowych, fot. E.M. Welc

Fig. 5. Representatives of the "Geotourism" Group (from left: Catherine Pazio and Martyn Gaik) during the XVIIth Seminar of of the Student's Scientific Association, phot. E.M. Welc • Przedstawicielki KN „Geoturystyka” (od lewej: Katarzyna Pazio i Martyna Gaik) podczas XVII Seminarium Kół Naukowych, fot. E.M. Welc

Fig. 6. The highest peak of the Table Mts. - the Great Szczeliniec Mt. as a background for happy members of the "Geotourism" Group, phot. J. Muzyk • Szczeliniec Wielki, najwyższy szczyt Gór Stołowych jako tło dla uradowanych wyjazdem kołowiczów, fot. J. Muzyk

Up to now, we completed several field sessions during which we prepared documentation of selected sites (Fig. 3). The results were presented to the public in October, 2012 during the XVIIth Session of the Student's Scientific Association (Fig. 4, 5).

The sessions of the Mining Engineering Group of the Student's Scientific Association has become a tradition at the AGH-UST. Since many years the association members have been preparing short presentations on various scientific topics and have presented them to the students and staff members. For example, in December, 2011, during the LIInd session, our colleagues gave 13 lectures dealing mostly with the development of various geosites for tourism and geotourism. The presentations were appreciated by the attendants for passion and high scientific values. The next, LIIIrd Sessions has already been announced and we plan to prepare further developments resulting from our scientific activity.

Obviously, the science is not the only subject of our interest. Similarly important for tourists are excursions. In 2012 we organized the field trip to the Table Mts. (Fig. 6) in order to recognize the geological structure of that unusual place and to evaluate the development of the area for tourism industry. Hence, we visited the Adršpašské skály in Czech Republic (Fig. 7, 8) and the Great Szczeliniec in Poland (Fig. $9,10)$ as well as some attractions in the Kłodzko Depression (Fig. 11, 12) famous of its scenic valours (Fig. 13).

In the near future we will celebrate the 10th anniversary of our "Geotourism" Group. There are some ideas concerning this celebration, among others the next thematic session, this time devoted to Georgia. We also plan to run several field sessions which would extend our knowledge, both geological and practical, related to the methods of development of areas and sites for geotourism.

In 2013 we plan a trip to Germany in order to attend the International Tourism Fair in Berlin and much longer journey to Kazakchstan in order to prepare the development project for the national park in Alma-Aty vicinity. We hope our ambitious plans will become realistic and we will gain new experience in tourism and geotourism. 

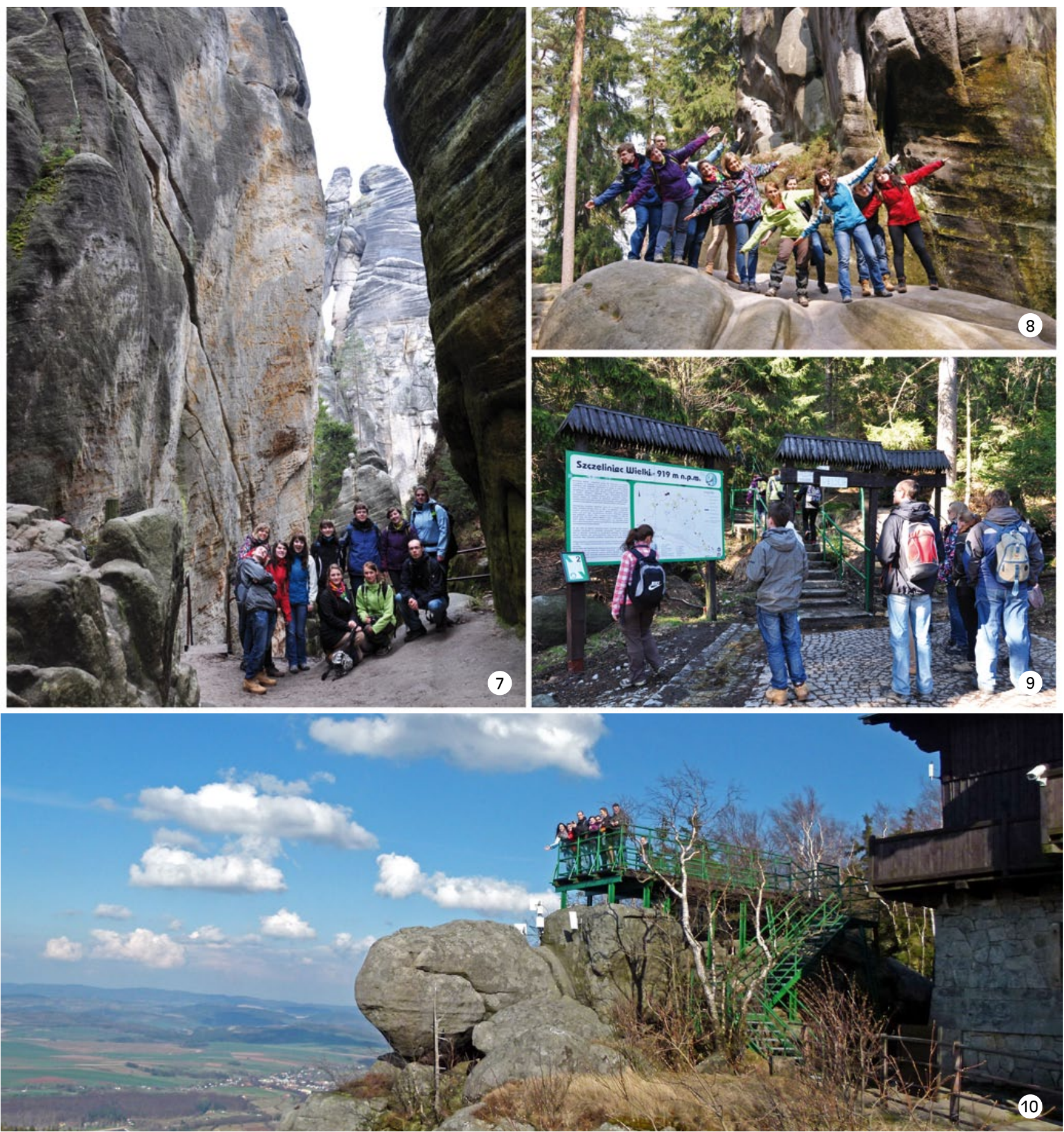

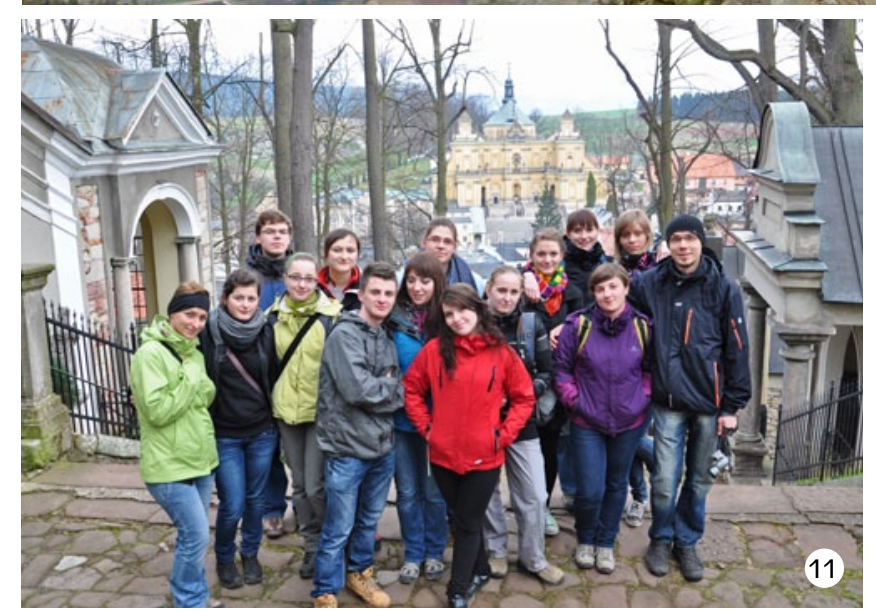

Fig. 7. Geotourists from the AGH-UST in the Adršpašské skály Natural Reserve, phot. E.M. Welc • Geoturyści z AGH w rezerwacie Ardszpaskie Skały w Czechach, fot. E.M. Welc

Fig. 8. Students apparently enjoy scientific excursions - in the Adršpašské skály Natural Reserve, phot. E.M. Welc • Studenci wyraźnie lubią wyjazdy naukowe - w rezerwacie Ardszpaskie Skały, fot. E.M. Welc

Fig. 9. On the trail to the Great Szczeliniec Mt., phot. E.M. Welc • W drodze na Szczeliniec Wielki, fot. E.M. Welc

Fig. 10. Students from the "Geotourism" Group at the top of the Great Szczeliniec Mt., phot. J. Muzyk • Kołowicze na szczycie Szczelińca Wielkiego, fot. J. Muzyk

Fig. 11. The cultural and religious aspects of excursion to the Table Mts. - the Wambierzyce Sanctuary, phot, E. M. Welc • Kulturowo -religijny aspekt wyjazdu w Góry Stołowe - Wambierzyce, fot. E.M. Welc 


\section{Tłumaczenie}

\section{Nie samą nauką żyje student, czyli fotorelacja z działalności KN ,Geoturystyka” Mateusz Birówka}

Koło Naukowe „Geoturystyka”, działające na Wydziale Geologii, Geofizyki i Ochrony Środowiska na Akademii Górniczo-Hutniczej im. Stanisława Staszica w Krakowie, już prawie od dziesięciu lat łączy studentów, których pasją jest geoturystyka. W jego szeregach działa obecnie ponad dwudziestka aktywnych i rządnych wiedzy młodych ludzi, głównie studentów kierunków turystyka i rekreacja oraz górnictwo i geologia.

W 2012 roku członkowie KN Geoturystyka podjęli szereg działań prowadzących do poszerzania swej wiedzy geoturystycznej oraz zdobywania nowych doświadczeń.

Jednym z pierwszych wyzwań była organizacja własnego stanowiska promocyjnego podczas Dni Otwartych AGH (Fig. 1). Kolejnym wyzwaniem stała się organizacja pierwszej z cyklicznych imprez - wieczoru argentyńskiego, zatytułowanego „Argentyna - geodziedzictwo Parków Narodowych", która stała się wspaniałą okazją do poznania atrakcji turystycznych i geoturystycznych tego południowoamerykańskiego kraju. Impreza była świetną okazją do wysłuchania opowieści o Argentynie, przygotowanej przez dr. hab. inż. Marka Doktora, a dzięki własnoręcznie przygotowanym argentyńskim potrawom, do poznania tego kraju „od kuchni““ (Fig. 2).

Nieodłącznym elementem działalności KN Geoturystyka jest tworzenie projektów geoturystycznych. Cały rok 2012 upływa pod znakiem finalizowania II etapu projektu grantu rektorskiego, którym członkowie koła zajmują się od dwóch lat. Projekt dotyczy zaprojektowania dla Ojcowskiego Parku Narodowego tablic geoturystycznych, opisujących procesy geologiczne i krasowe we wskazanych przed pracowników parku miejscach. W związku z tym przedstawiciele Koła kilkakrotnie odwiedzili obszar parku w celu przeprowadzenia obserwacji terenowych i wykonania niezbędnej dokumentacji fotograficznej (Fig. 3). W październiku, podczas XVII Seminarium Kół Naukowych (Fig. 4), przedstawicielki KN „Geoturystyka” (Fig. 5) zaprezentowały projekty zagospodarowania Ojcowskiego Parku Narodowego.

Jeśli mowa o projektach naukowych, należy tu wspomnieć coroczne Studenckie Sesje Naukowe Pionu Górniczego, w których członkowie KN „Geoturystyka” rokrocznie biora czynny udział. W grudniu 2011 roku odbyła się LII Sesja, studenci wygłosili wówczas 13 referatów, proponując liczne pomysły na zagospodarowanie turystyczne i geoturystyczne wybranych przez siebie obiektów. Wystąpienia członków Koła stały na wysokim poziomie, świadcząc o kreatywności i zaangażowaniu uczestników w przygotowywane przez siebie projekty. Zbliża się kolejna, LIII Sesja Kół Naukowych, na której z pewnością nie zabraknie przedstawicieli KN „Geoturystyka” - prace nad własnymi projektami trwaja.

Oczywiście nie samą nauką żyje człowiek. Jak na turystów przystało, od czasu do czasu warto wyruszyć na wspólną wyprawę. W tym roku idealnym momentem był początek wiosny. Zorganizowany został wówczas wyjazd szkoleniowy w Góry Stołowe (Fig. 6), którego celem było zapoznanie się z budową geologiczną tego obszaru, a także możliwościami zagospodarowywania obiektów geoturystycznych na przykładzie Adrszpaskich Skał w Czechach (Fig. 7, 8) czy Szczelińca Wielkiego (Fig. 9, 10). Dodatkowo, członkowie koła zwiedzili kilka atrakcji turystycznych Kotliny Kłodzkiej (Fig. 11, 12), która słynie z niepowtarzalnych walorów krajoznawczych (Fig. 13).

Koło zbliża się do swego dziesięciolecia, zaś plany jego członków są coraz bardziej ambitne. W najbliższym czasie planowane jest kolejne spotkanie tematyczne, tym razem obiektem zainteresowania stanie się Gruzja. Ponadto odbędzie się kilka wyjazdów terenowych w celu poszerzania wiedzy, a także poznawania sposobów i metod tworzenia projektów zagospodarowania geoturystycznego.

W planach Koła na rok 2013 znalazł się wyjazd do Niemiec połączony z udziałem w Międzynarodowych Targach Turystycznych w Berlinie, zorganizowanie Wyjazdowej Sesji Naukowej oraz wyjazd do Kazachstanu, w celu stworzenia projektu zagospodarowania geoturystycznego Parku Narodowego w rejonie Ałmaty. Pozostaje sobie życzyć, by wszystkie ambitne plany na nadchodzący czas doszły do skutku i obfitowały w szereg nowych, przydatnych doświadczeń. 